This item was submitted to Loughborough's Research Repository by the author.

Items in Figshare are protected by copyright, with all rights reserved, unless otherwise indicated.

\title{
River use profile of the Central Niger Delta based on traditional eco- livelihood knowledge (TELK)
}

PLEASE CITE THE PUBLISHED VERSION

PUBLISHER

(c) Springer Netherlands

LICENCE

CC BY-NC-ND 4.0

REPOSITORY RECORD

Tamuno, P.B.L., Guy Howard, and Michael D. Smith. 2019. "River Use Profile of the Central Niger Delta Based on Traditional Eco-livelihood Knowledge (TELK)". figshare. https://hdl.handle.net/2134/3664. 
This item was submitted to Loughborough's Institutional Repository by the author and is made available under the following Creative Commons Licence conditions.

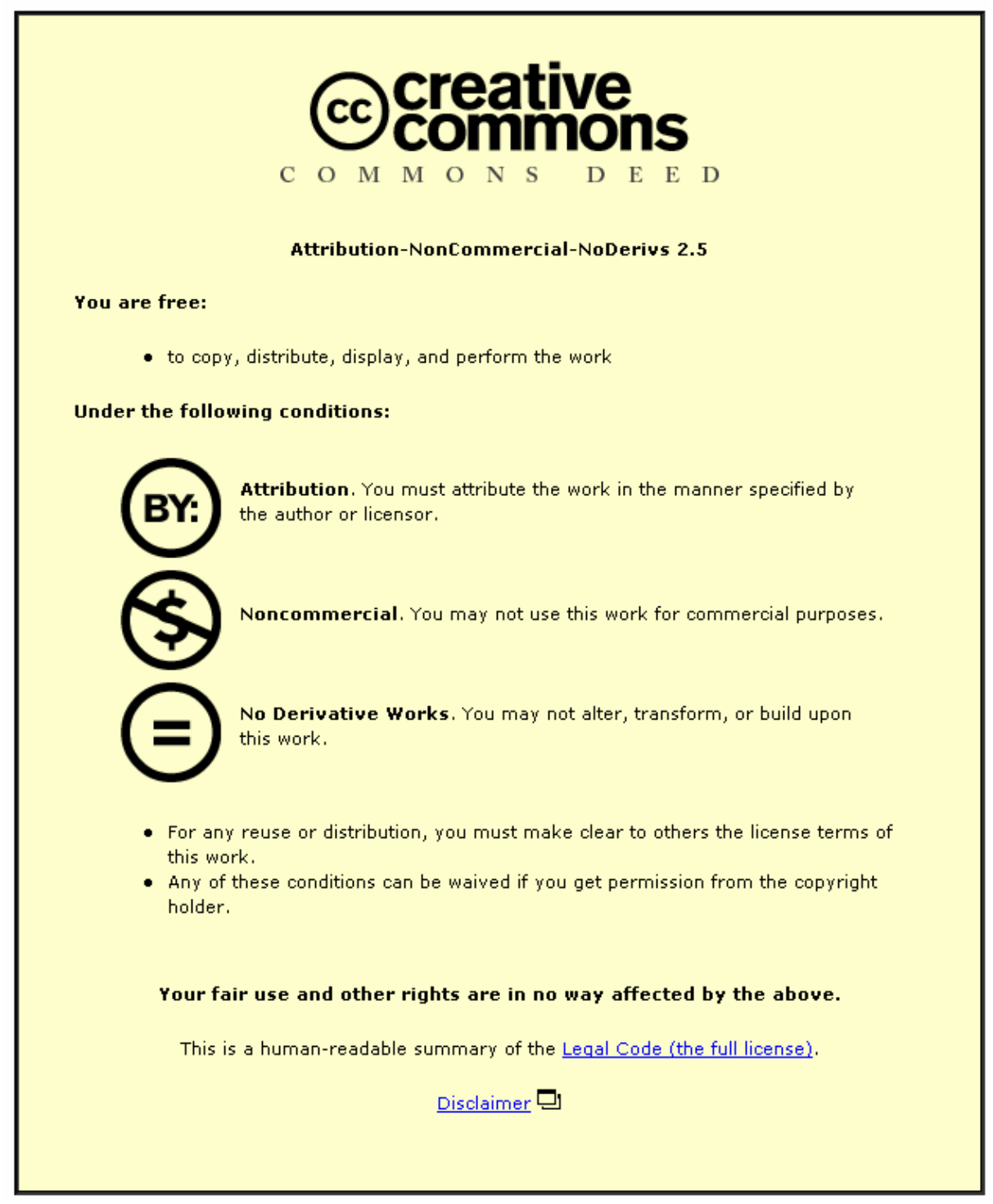

For the full text of this licence, please go to: http://creativecommons.org/licenses/by-nc-nd/2.5/ 


\title{
River use profile of the Central Niger Delta based on traditional eco-livelihood knowledge (TELK)
}

\author{
${ }^{1}$ Tamuno, P.B.L'., ${ }^{2}$ Howard, G., and ${ }^{1}$ Smith, M.D. \\ ${ }^{1}$ Water, Engineering and Development Centre (WEDC), Loughborough University, LE11 3TU, United Kingdom \\ ${ }^{2}$ Climate and Environment Group, DFID Abercrombie House, East Kilbride, Glasgow, G75 8EA, UK \\ Received: 31 December 2007 / Accepted: 10 June 2008 Springer Science+Business Media B.V. 2008
}

\section{Abstract}

The Central Niger Delta is made up of a network of rivers and creeks that constitute the inland surface waters. These surface waters have historically influenced settlement patterns and are of diverse use to residents of the Central Niger Delta. Surface water like many ecological system are complex, whose complexity has been associated with seasonal variability. Traditional knowledge (TK), traditional ecological knowledge (TEK) and the traditional eco-livelihood knowledge (TELK) of residents of four rural communities in the Central Niger Delta have been explored in developing a river use profile of rural communities of the Central Niger Delta. A questionnaire survey has been carried out in four communities, two each from the Otuoke and Kolo Creeks. The result shows that river use varies across seasons and affected by: physicochemical water quality and characteristics of surface water; the hydrological characteristics; the biological / ecological characteristics; cultural use and demand; need for development projects; and access to this vital resource. Fishing constitute one of the major livelihood source in the Central Niger Delta and the TELK of fishers in the sample communities have specifically been explored to understanding fishing patterns across seasons. The five seasons identified from this study are: flood season; flood recession season; dry season; early rainy season; and rainy season. Therefore, the thesis of this paper is that there is the need to balance the current usage of surface water in the developing world such as the Central Niger Delta with the demand for development as well as future use if development is to meet the criteria for equitable development. The river use profile could be a promising tool in planning for equitable development.

Key words: Traditional eco-livelihood knowledge (TELK); surface water; fishing seasons; river use profile; Kolo Creek; Otuoke Creek; equitable development.

\footnotetext{
' Corresponding Author: Email: pbltamuno@hotmail.com Fax: +44(0)1509211079
} 


\subsection{Introduction}

Surface water resources play a key role in most economic activities, particularly in developing countries, ranging from agriculture to industry, and fishing. Fishing in many parts of the world is a major source of income for the inhabitants of rural communities (Adolph, et al. 2001; Osman, et al. 2001). Specifically, fisheries are important common pool resources (CPRs) in a number of Latin American countries, not only contributing to export earnings, but also providing invaluable employment opportunities in coastal regions (Ibarra, et al. 2000). In the Niger Delta, fishing is a major livelihood component in the Niger Delta region of Nigeria (Sikoki and Otobotekere, 1999; Abam, 2001; Tamuno, et al. 2007). In addition, Lake Chad provides the basis of many thousands of livelihoods which depend on its seasonal fluctuations to renew fish stocks, farmland and rangeland (Sarch, 2001).

The benefits people derive from ecological systems represent ecosystem services (Daily, et al. 2000; Miller, 2002). The main feature of ecosystem services is that such an approach allows the integration of ecological and social aspects of ecosystem management into environmental policy and decision making systems. The first dominant appearance of the concepts of ecosystem services in scientific discuss was in the early 1970s, but its development has received remarkable attention in recent years (Bolund and Hunhammar, 1999; De Groot, et al. 2002; Maass, et al. 2005). Understanding and integrating ecosystem services into planning for sustainable development is a progressive approach towards achieving the tenet of equitable development. Such an approach recognises that human is an integral component of the ecosystems.

As a service provider, freshwater rivers constitute the basis for most productive activities (Maass, et al. 2005). Specifically, most tropical rivers play a major role in the livelihoods of rural dwellers along these rivers, but access to these resources varies annually across season (Hartmann, 2003; Kgathi, et al. 2006). Surface water continue to remain a natural resource on which the livelihoods of both the rich and the poor are directly or indirectly dependent (Beck and Ghosh, 2000; Gupta, et al. 2001). Until the early 1970s, the Swampy Cree community of Southern India depended on commercial fishery. In 1970, a dam was constructed along the outflow of the lake submerging the community and adversely affecting commercial fishery. The community was relocated to a place with modern houses and a recreational complex. However, the recreational facilities do not seem to have replaced fishing, trapping, and hunting as a centrepiece for these people's lives. Poverty, depression, and alcohol abuse have resulted (Rosenberg, et al. 1995). Due to the failure of such top-down management strategy, there has been active interest in promoting people-focused approach to managing natural resources (Muller and Vickers, 1996). For example, the Community-Based Natural Resources Management (CBNRM NET) provides 
opportunities for communication and networking capabilities for the purpose that makes it possible for people to exchange and manage experience and knowledge that explores participatory approaches that put communities, their culture and knowledge at the centre of planning for better water resources management (ARD-RAISE Consortium, 2001).

Furthermore, despite decades of efforts aimed at protecting and conserving surface water resources, there have been a continuous decline in the value of this vital resource, because the management of this resource is increasingly becoming difficult (Biswas, 1997; Karr and Chu, 1999). One of such difficultly is associated with the multi-stakeholder demand on surface water that may often be divergent or contrasting; as well as the need to balance the need for economic growth and development with environmental protection, and localised service value attached to surface water resources. The contrasting demand and the inherent variability and complexity of environmental systems make it more difficult to manage the environment. This therefore calls for water resource management (WRM) approaches that can highlight and appropriately incorporate the priorities of local people that often bear the impacts of development project as well as address the issue of equitable development. Equitable development implies identifying ways in which localised impacts of development can be appropriately reduced or mitigated as well as enhancing the localised benefits of development projects; in essence such an approach encourages fair opportunities to access, use and preserve nature. However, the current drivers for development are environmental protection, appropriate and cost-effective technology and national or regional economic growth. This paper is aimed at exploring the knowledge of residents of rural communities in the Central Niger Delta to understanding the localised benefits or significance of surface water resources, as well as the seasonal variation of fish production in rural communities of the Central Niger Delta. The knowledge of local people of areas such as the Central Niger Delta in which surface water is of a significant socio-economic relevance can be incorporated into WRM planning for sustainable development particularly when the surface water plays a key development role that may impact on the localised benefits of surface water.

\subsection{Theoretical concept and application of traditional knowledge}

The knowledge of rural people about their local environment is adaptive, dynamic and constitutes an integral perspective of the historical resource use pattern and survival strategies, and has been driven by resource availability and local community demands (Warren and Rajasekaran, 1993; Berkes, et al. 2000; Olsson and Folke, 2001; Sillitoe, et al. 2002; Johnson, 2003), this interactive knowledge have been accumulated over centuries (Klubnikin, et al. 2000). Therefore, traditional knowledge (TK) has been simply defined as a form of logical, systemic and reliable 
knowledge gained through residency, intimate contact by peoples with their environment (UNEP, 1998; Huntington, 2000) that has equal status as scientific knowledge (Ellen and Harris, 1996; UNEP, 1998; Berkes, et al. 2000). TK has some parallels with western science because it is knowledge that is acquired by local people through observation, the accumulation of experiences and informal experiments, and through an intimate understanding of the environment in a given socio-geographical context (Warren and Rajasekaran, 1993; Berkes, et al. 2000). However, TK is different from science because science is concrete, while TK abstract (Berkes, et al. 2000). In the context of this paper, TK has been used to represent local knowledge acquired from experience based on residency.

Most of the world's biodiversity occurs on or adjacent to traditional indigenous territories (Nabhan, 1997), from which some rural people from most developing countries earn their livelihood (Tamuno, et al. 2003b). It is very unfortunate that the concerns, experience and knowledge of rural peoples have often been ignored in the formulation of environmental and water resource policy; rather most development policies and projects have primarily relied on data from "hard science".

Traditional ecological knowledge (TEK) is a relatively recent area of academic research, the concept and associated theorising and research have been around since the mid-1970s (Berkes, 1999); but the main feature of TEK is long term residency and knowledge about the local environment, which is not a recent concept (Paci, et al. 2002). TEK constitutes a cumulative body of knowledge, understanding, practices, and beliefs about the relationships of living beings (human inclusive), to one another and the abiotic components of the environment and is culturally intra- and intergenerational exchanged (Gadgil and Berkes, 1991; Gadgil and Berkes, 1993; Nabhan, 1997; Fernadez-Gimenez, 2000; Olsson and Folke, 2001). TEK represents cumulative experience (CE) of local people about their environment (Fernadez-Gimenez, 2000). Generally, the concept of TEK refers to the knowledge held by people that are resident in a specific geographical location with a long standing experience, understanding and knowledge about their local environment.

One of the most difficult tasks in achieving the integration of ecological and social characteristics is developing a framework for research and planning that views science and TK or TEK as complementary forms of knowledge. However, despite over two decades of efforts towards involving local peoples in the management of their environment, there is a dearth of reported cases of actual involvement of these people in the management and conservation of their environment (Klubnikin, et al. 2000; Nepal, 2002). Traditional eco-livelihood knowledge (TELK) is the localised knowledge of residents of a particularly geographical knowledge that is used for the 
purpose of earning a livelihood from the environment. TELK is different from TK and TEK because this adaptive knowledge about the local environment is used for the purpose of earning and winning a livelihood from their environment.

In addition to providing important information that have helped to increase the relevance of scientific research, the use of TK and TEK has facilitated developing environmental policies in Canada that recognise and incorporate cultural values (Gilchrist, et al. 2005). Moreover, the use of TEK in scientific investigations gives local stakeholders an opportunity to be members of a team responsible for addressing shared conservation objectives. Such an approach is generally more productive than the sole use of scientific studies. The priorities and knowledge of local peoples have often been disregarded in environmental and water resource policy formulation. Rather, most development projects have relied solely on data and information from "hard science" and technology. The integration of the tenets of TELK into water resources management strategy may serve as a tool that could link the social, livelihoods priorities, and the demand for sustainable development.

However, there is a distinct difference between what local or indigenous people interpret as "significant" impacts and what environmental professionals and policy-makers regard as significant impacts. This poses an obstacle on both the effective monitoring of impacts and the possible incorporation of TK into environmental assessment and management (Sallenave, 1994). Each individual has unique economic, practical, political, and historical relationships to his and her community, which implies that even within indigenous societies, TK is not homogenous. For example differential knowledge among women and men in areas of aquatic and terrestrial resource management is common (Turner, et al. 2000). The consultation of a wide range of socio-economic groups within communities under investigation may be able to reconcile the difference in opinion to arrive at an objective representation of experience and knowledge of local people.

Furthermore, despite much discussion on the need to integrate these two systems, there are a few attempts to establish co-management institutions. The effective use of TK in decision-making is yet to be fully tested and established (Wolfe, et al. 1992). One of the reasons for this may be as a result of the fact that the knowledge of local people are often difficult to generalise outside the cultural and or geographical context in which it exist. Hence, experiences that has been documented about one social group may be exclusive to that group alone and may not be useful outside its social and political contexts (Sallenave, 1994; Berkes, et al. 2000). Furthermore, the gradual disappearance of TK has been associated with the absence of established documentation system for this type of knowledge. It is only through documentation and the 
cooperation of all residents of rural areas that the usefulness of TK can become apparent and fully appreciated (Johnson, 2003). Therefore, there is the need to document and appropriately use TK in environmental management and in planning for equitable development so that benefits of TK can be harnessed.

\subsection{Methodology}

Figure 1 shows that the four sample communities are independent of each other and are located along two creeks. Otakeme and Otuogidi are located along the Kolo Creek, while Elebele and Otuoke are situated along the Otuoke Creek. As shown in Figure 1, there is a proposed network of roads to be constructed all of which are over inland river in the Study Area, which is typical of the Central Niger Delta. Road and bridge construction is one of the development projects that are carried out in the Central Delta that could affect the local river usage. Alagoa (1999), stated that the Central Delta is the least infrastructural developed of the thirty six states of Nigeria and the creation of Bayelsa State on the $1^{\text {st }}$ of October 1996 have given rise to an unprecedented increase in construction in response to the development needs of the Central Delta. The current construction works carried out in the Central Delta relies on sand dredged from inland rivers; the impacts of dredging for sand mining is often localised.

Residents of the sample communities that are at the time of the fieldwork (year 2004) of the age of twenty years and above have been identified as the target population. Similarly, Tamuno (2001) used twenty years as the base age for selecting respondents for a study conducted in the Central Delta in 2001 in investigating appropriate flood mitigation options for the Central Niger Delta. Face-to-face (interview) administered questionnaires have been completed by the first author for $5 \%$ of the target sample population. The questionnaires contain questions aimed at accessing the river usage in the sample communities across seasons as well as understanding the variation in fish production across season in a typical year. Fishing has been used because fishing constitutes one of the major livelihood sources as well as one of the major uses of inland rivers in the Central Delta. The questionnaire on fish production was administered to fishers because this category of respondent have specialist knowledge about fishing in the Central Delta. Face-to-face questionnaires have been found to be useful in eliminating no-responses from respondent and reliable for direct observation of the authenticity of responses (Budds, 1999). By and large, questionnaires administered face-to-face make the data collection process very interactive, and informal.

\section{Figure 1 Map of the Study Area showing the Sample Communities}




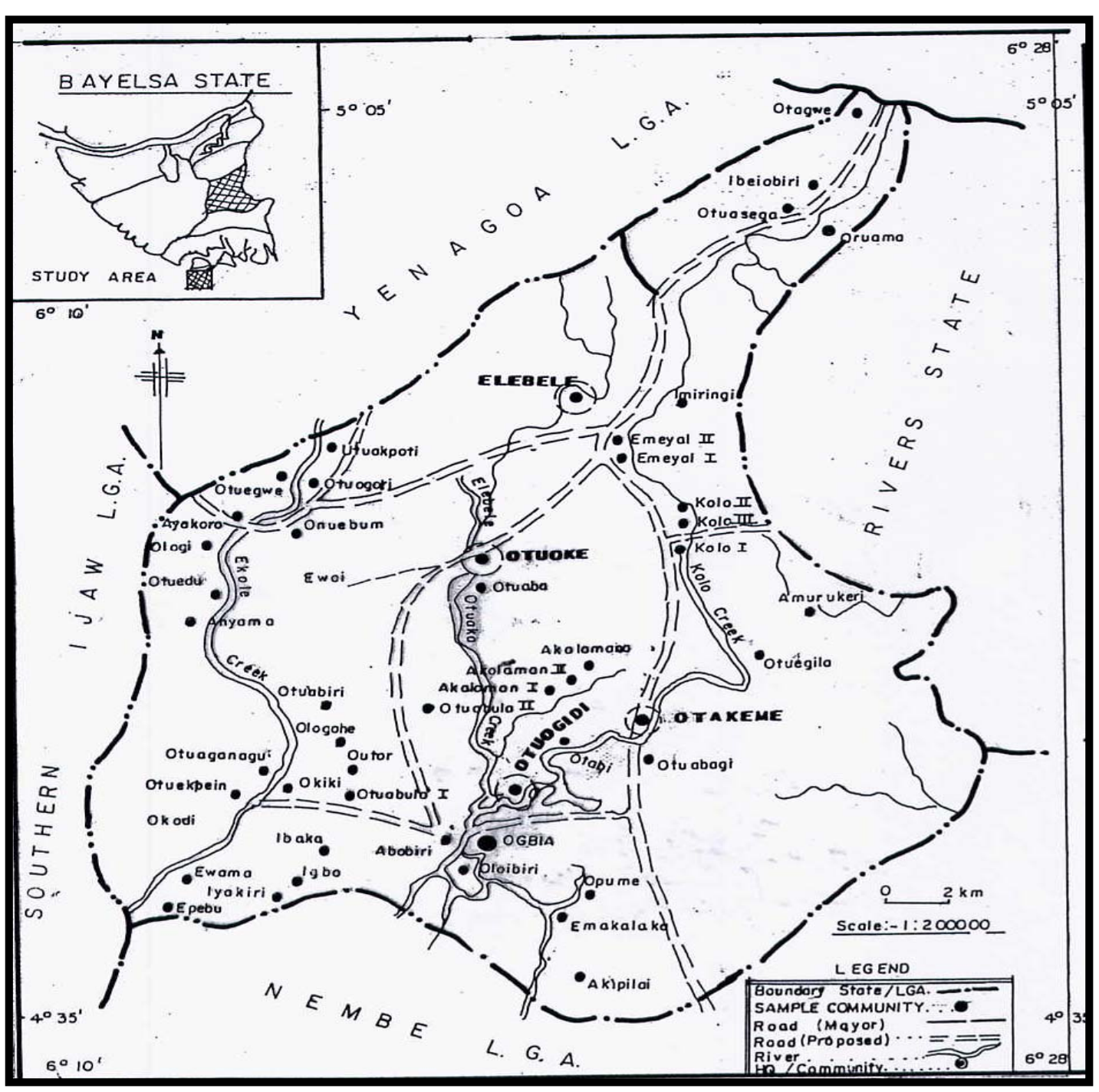

The questionnaire has been administered to a total of 418 respondents from the sample communities (by simple random sampling), of these: 81 were from Elebele; 103 were from Otuoke; 108 were from Otuogidi; and 126 were from Otakeme. The sample population was used for the purpose of making the survey as cost-effective as possible without compromising the objective of accessing the TK and TEK of a fair representation of the target population. Obtaining the perceptions of more respondents across the socio-economic segment of the sample communities tends to increase the level of confidence, as well as improve the statistical validity of the outcome of the social survey.

The target respondents have been divided into: specialist groups and non-specialist groups. In the context of this study, inland river fishers have been used as the specialist group to obtain information based on their knowledge and experience that have been used for earning livelihoods 
from the environment. This type of experience and knowledge constitute traditional eco-livelihood knowledge (TELK). All other respondents belong to the non-specialist group. Hence, two types of questionnaires have been used for the purpose of this study for each group and 116 of the 418 respondents from the sample communities are fishers, of which: 18 (22.2\%) Elebele; $33(32 \%)$ Otuoke; 35 (27.8\%) Otakeme; and 30 (27.8\%) Otuogidi. This represent between 22.2 to $32 \%$ of the respondents from the respective sample communities.

The questionnaire designed specifically for inland river fishers was for the purpose of obtaining information about fish production during the fishing seasons. The second questionnaire has been used for Non-fishers, and intended to obtaining generic information about the use of the surface water. Similarly, Ghimire et al. (2004) conducted an ethno-ecological field study in the Himalayas of Nepal between 1997 and 2003, in which respondents has been categorised into specialist and non-specialist groups. In the study by Ghimire et al. (2004) the specialist respondents were those for whom the National Park is a major component of their life, while the non-specialists are those for whom the National Park are not an important component of their life, but who may occasionally use the National Park.

All respondents (fishers and non-fishers alike) gave their consent to participate in the social survey and the respondents were informed that the survey was purely for an academic research purpose. The English language and or "Pidgin English",ii have been used in administering the questionnaires. In some cases the questionnaire has been administered through an interpreter (Ogbia is the native language spoken in all the sample communities). An interpreter has been used for simplicity of administering the questionnaire, and the questioner's knowledge of the local language help to check that the questions were not mis-represented by the interpreters. Furthermore, the consents of respondents were sought for the discussion to be recorded with a microcassette recorder. The recordings of the discussion have been done in conjunction with the direct filling out of the response from respondents by the author in the course of administering the questionnaires.

The limitation of adopting questionnaire survey is that the information gathered from respondents may be subjective. However, administering the questionnaire to 418 respondents was done for the purpose of improving the level of confidence of using this research approach. Documenting the TK, TEK and TELK of such a large number of respondents is one way of accessing the experience, knowledge and perception of a wide range of resident of the Study Area. In addition

\footnotetext{
ii this is a colloquial form of English language, generally spoken and understood by majority of the people from different ethnic background in southern Nigeria
} 
statistical analyses have been used to identify level at which the results could be accepted as significant, such an approach reduces the impacts of subjective responses on the study result.

\subsection{Results and analyses}

River use profile has been investigated and analysed based on seasonal variation in the Study Area. Table 1 shows a summary of the river use profile of the Study Area based on the knowledge and experience (TK, TEK and TELK) of respondents (represented by percentage of respondents), and shows that there is seasonal variation in river usage. The seasonal variation has been represented by the percentage of respondents.

The use of the creeks for drinking and domestic use has been consistent across seasons; inland river fishing is most viable during the flood recession season; rainy and flood seasons have been the most favourable seasons for lumbering; palm cutting and processing and the use of the creeks for irrigation and recreation is highest during the dry season across the Kolo Creek. Both Otuoke and Kolo creeks have been used for recreation purposes, but respondents from Elebele and Otuoke did not consider recreation as constituting usage. This does not however imply nonuse of the river for recreation, but non-response. 
Table 1 River use profile of the Central Niger Delta

\begin{tabular}{|c|c|c|c|c|c|c|c|c|c|c|c|}
\hline & & \multicolumn{10}{|c|}{ River Use profile } \\
\hline Community & Season & FISHING & DOMESTIC & TRANS / CO. & SAND MINE & LUMBER & DISPOSAL & PALM PS. & RECREATE & FISH FEST. & IRRIGATE \\
\hline \multirow[t]{5}{*}{ Elebele } & Rainy & 10 & 100 & 100 & 0 & 3 & 12 & 0 & 999 & 999 & 999 \\
\hline & Flood & 6 & 100 & 100 & 0 & 3 & 12 & 0 & 999 & 999 & 999 \\
\hline & After Flood & 83 & 100 & 100 & 0 & 0 & 12 & 7 & 999 & 999 & 999 \\
\hline & Dry & 51 & 100 & 100 & 24 & 0 & 12 & 84 & 999 & 999 & 999 \\
\hline & Early Rains & 3 & 100 & 100 & 5 & 0 & 12 & 84 & 999 & 999 & 999 \\
\hline \multirow[t]{5}{*}{ Otuoke } & Rainy & 21 & 100 & 100 & 0 & 18 & 7 & 1 & 999 & 999 & 0 \\
\hline & Flood & 5 & 100 & 100 & 0 & 18 & 7 & 1 & 999 & 999 & 0 \\
\hline & After Flood & 64 & 100 & 100 & 0 & 0 & 7 & 11 & 999 & 999 & 0 \\
\hline & Dry & 38 & 100 & 100 & 4 & 0 & 7 & 91 & 999 & 999 & 1 \\
\hline & Early Rains & 10 & 100 & 100 & 4 & 0 & 7 & 89 & 999 & 999 & 0 \\
\hline \multirow[t]{5}{*}{ Otakeme } & Rainy & 8 & 100 & 100 & 0 & 21 & 19 & 2 & 0 & 0 & 0 \\
\hline & Flood & 3 & 100 & 100 & 0 & 21 & 19 & 2 & 0 & 0 & 0 \\
\hline & After Flood & 64 & 100 & 100 & 2 & 2 & 19 & 9 & 0 & 0 & 0 \\
\hline & Dry & 56 & 100 & 100 & 30 & 2 & 19 & 79 & 5 & 0 & 2 \\
\hline & Early Rains & 36 & 99 & 100 & 21 & 2 & 19 & 83 & 1 & 1 & 1 \\
\hline \multirow[t]{4}{*}{ Otuogidi } & Rainy & 12 & 100 & 100 & 0 & 18 & 13 & 2 & 0 & 999 & 0 \\
\hline & After Flood & 74 & 100 & 100 & 1 & 0 & 13 & 13 & 0 & 999 & 0 \\
\hline & Dry & 56 & 100 & 100 & 9 & 0 & 13 & 90 & 4 & 999 & 1 \\
\hline & Early Rains & 18 & 100 & 100 & 9 & 0 & 13 & 91 & 2 & 999 & 0 \\
\hline
\end{tabular}

\begin{tabular}{|l|l|}
\hline \multicolumn{2}{|l|}{ Key } \\
\hline None & $0 \%$ \\
\hline Very low to low & $0>25 \%$ \\
\hline Low to medium & $25>50 \%$ \\
\hline Medium to high & $50>75 \%$ \\
\hline High to very high & $75>100 \%$ \\
\hline
\end{tabular}

FISHING - Inland river fishing; DOMESTIC - Domestic and Drinking; TRANS / CO. - Transportation and Commerce; SAND MINE - Sand mining; LUMBER - Lumbering; DISPOSAL - Sewage and waste disposal; PALM PS. - Palm processing; RECREATE - Recreation; FISH FEST. - Fishing festival; IRRIGATE - Irrigation; 999 - Non-use (code that is easy to isolate from other percentages) 
The K-S Test for normal distribution on the river use variables (these variables are represented by the percentage of respondents on each of the ten use value in Table 1) shows a deviation from normality $(p<0.05)$ for river use categories in different seasons for each sample community. Kendall's tau $(\tau)$ coefficient of correlation has been carried out on the river usage based on the summary in Table 1. Kendall's tau $(\tau)$ is the most appropriate non-parametric correlation test for small data size (Field, 2005). Table 2 shows that there is a significant positive linear relationship in river usage in all communities in the Study Area; hence implying consistency in river usage across the sample communities.

Table 2 Relationship of river use profile in the Study Area

\begin{tabular}{|l|l|l|l|l|}
\hline & \multicolumn{1}{|c|}{$\begin{array}{c}\text { River Use } \\
\text { (Elebele) }\end{array}$} & $\begin{array}{c}\text { River Use } \\
\text { (Otuoke) }\end{array}$ & $\begin{array}{c}\text { River Use } \\
\text { (Otakeme) }\end{array}$ & $\begin{array}{c}\text { River Use } \\
\text { (Otuogidi) }\end{array}$ \\
\hline River Use (Elebele) & 1.00 & & & \\
\hline River Use (Otuoke) & $0.808^{\star \star}$ & 1.00 & & \\
\hline River Use (Otakeme) & $0.838^{\star \star}$ & $0.862^{\star \star}$ & 1.00 & 1.00 \\
\hline River Use (Otuogidi) & $0.826^{\star \star}$ & $0.943^{\star \star}$ & $0.925^{\star \star}$ & \\
\hline
\end{tabular}

** Significant at 0.01 level (2-tailed)

The Kruskal-Wallis Test has also been carried out on each river use variable identified by respondents. The result in Table 3 shows that there is no significant difference $(p>0.05)$ in river usage on all river use variable except sewage and waste disposal; this may be due to the fact that most residents in the Study Area do not view sewage into rivers and waste disposal as river usage. However, disposal of sewage and waste into surface water is common practice in the Niger Delta (Egborge, 1980; Akinluyi and Odeyemi, 1984; Tamuno, 2001).

There is no significant difference on river usage for irrigation. All sample communities considered the use of surface water for irrigation to be of little significance, except Elebele. Elebele respondents did not consider irrigation as a use value, most likely because irrigation is a minor usage that is restricted to the short dry season in the Study Area. The dry season in the Niger Delta is comparatively short and lasts for about three months, during which period there are usually occasional rainy days (Abam and Okagbue, 1986; Okagbue, 1989; Gobo and Abam, 1991; HRW, 1999). Therefore the cultural and societal values of the creeks are not significantly different in the Study Area. In addition, the creeks have been used for recreation and general purposes (drinking and domestic use, recreation, fishing festival and sewage and waste disposal) and for livelihood sustenance (fishing, transportation and commerce, palm processing; irrigation; lumbering and sand mining). Similarly, in Togo-Benin, rivers have also been used for a variety of purposes, including domestic uses and navigation (Trebaol, 2003). 
Table 3 Kruskal Wallis H Test of River use between the Samples Communities

\begin{tabular}{|l|l|l|l|l|}
\hline \multicolumn{1}{|c|}{ Variables } & Chi square & \multicolumn{1}{c|}{ Df } & \multicolumn{1}{c|}{ P-values } & \multicolumn{1}{c|}{ Remarks } \\
\hline Fishing (Inland River) & 0.100 & 3 & 0.993 & Not significant \\
\hline Drinking and Domestic Use & 3.000 & 3 & 1.000 & Not Significant \\
\hline Transportation and Commerce & 0.000 & 3 & 1.000 & Not Significant \\
\hline Sand Mining & 1.068 & 3 & 0.802 & Not Significant \\
\hline Lumbering & 3.376 & 3 & 0.335 & Not significant \\
\hline Sewage and Waste Disposal & 19.000 & 3 & 0.000 & Significant \\
\hline Palm Processing & 1.158 & 3 & 0.785 & Not Significant \\
\hline Recreation & 0.000 & 3 & 1.000 & Not Significant \\
\hline Irrigation & 0.900 & 3 & 0.725 & Not Significant \\
\hline
\end{tabular}

In the Study Area, inland river fishing constitutes one of the uses of the surface water. In the context of this research, face-to-face administered questionnaires have been used with fishers to understand the variation in fish production in the Central Niger Delta. Similarly, qualitative and semi-structured interviews used in Belize have provided detailed accounts of change in fishery, as well as used identifying key past events that may have affected fishery resources (Huitric, et al. 2005).

The river use profile has been developed based on the experience of the residents of communities located along these creeks. These residents have used the surface water for the purposes illustrated in Table 1. The TK and TEK of the respondents of the sample communities have been shown to be consistent irrespective of the sample communities. This knowledge source has been used to identify the most viable or suitable periods in a typical year that that each service value is most valuable, viable and productive. Such as: lumbering is mainly carried out during the rainy and flood season, because these seasons have been recognised by the residents of the Study Area as when the surface water discharge is high and the river flow is favourable for log and timber transportation; the restriction of sand mining to the dry season is based on the premise that this is the season when surface water level is low and sand demand is high particularly for building of houses, schools, hospitals, community centres and for general building projects, as well as when it is most easier for the sand miners to harvest sand from the river bed.

In addition, other river uses are influenced by the availability of resources such as palm processing that depends on the availability of ripe palm fruits, and palm processing sheds are located at the extremes of communities to reduce the pollution impact of effluents from processed palms; irrigation use is based on demand when there is less rains for the farm crops (particularly for dry season farming). Specifically the use of the creeks for fishing as discussed below has 
been based on seasons that fishing is most viable irrespective of the fact that fishing is an all year round livelihood activity.

Residents of the Study Area have used the surface water resources for services most beneficial to them, but any engineering development project that significantly alters the existing hydrological, ecological or structural balance could affect the localised use (see Table 1) of the surface water in the Central Delta. However, incorporating the localised services the residents of the Study Area derives from the surface water into WRM could help in appropriate planning to mitigate the impacts of development projects on such rural communities. The main limitation to the incorporation of TELK, TEK and TK into planning for equitable development is that arriving at a consensus may be difficult, but this difficulty can be reduced by consulting across a wide range of the socio-economic strata as well as statistically analysis the results to demonstrate the absence of bias by the researcher.

Table 1 show that the use of the creeks for drinking and domestic purposes is consistent all year round, but does not represent the variation in the quantity of surface water usage. Generally, the usage of the creeks as source of domestic and drinking water is reduced during the rainy seasons because rain water harvesting is a common practice in the Central Delta. Therefore, the application of TK and TEK to WRM should take into cognisance the distinct social context in which such experience and knowledge is derived without ignoring any relevant available scientific knowledge.

\subsection{Fishing in the Central Niger Delta}

Table 4 show a summary of the favourable and non-favourable fishing seasons in the Study Area based on the TELK of local fishers that have been acquired over years of fishing (this has been represented by percentage of fishers). The flood recession and the dry seasons are generally the most favourable fishing seasons, while the rainy and flood seasons are the non-favourable fishing seasons. Similarly, inland river fishing in the Niger Delta has been reported to be characterised by seasonal variations associated with intensive exploitation during the dry and low water period (flood recession), with decreased exploitation during the flood and rainy season when fish are dispersed unto the floodplains (Sikoki and Otobotekere, 1999; Laë, et al. 2003). In addition, traditionally, fishing in the Muni lagoon in Ghana, has been reported to show fish diversity across season (Koranteng, et al. 2000). Generally, fisheries of large river floodplains exhibit seasonal and inter-annual variations (Coates, et al. 2003; Laë, et al. 2003). Specifically, in the River Niger, fish species have adapted to these variations that are dependent on successions of favourable 
and unfavourable environmental conditions that affect the migration and distribution of fish species (Laë, et al. 2003).

Except Otakeme, the early rainy seasons (April and May) have been identified as a nonfavourable fishing seasons. The early rainy periods have been characterised by increased turbidity of the creeks as a result of run-off from the floodplains. It is a unanimous opinion of the fishers in the sample communities that increased turbidity may have resulted in migration of fish away from these creek sections during the early rainy season. However, local fishers in Otakeme feel differently, which may be because the early rains fall within the fishing festival in this community (see Table 4). Unfavourable seasons are seasons in which there is higher risk to fishing either due to high discharge / flow and high water levels during which fishing is considered risky or dangerous (as represented by the Rainy and Flood Seasons) and when fish production is lowest; hence, fishers embark on net mending and back swamp fish farming during this periods.

Table 4 Inland river freshwater fishing seasons based on TELK

\begin{tabular}{|c|c|c|c|}
\hline \multirow[b]{2}{*}{ Community } & \multirow[b]{2}{*}{ Perception } & \multicolumn{2}{|c|}{ Inland freshwater river fishing seasons (Percentage) } \\
\hline & & Favourable / "fishing" & Non-favourable / "non-fishing" \\
\hline \multirow[t]{5}{*}{ Elebele } & Rainy season & 17 & 67 \\
\hline & Flood season & 6 & 33 \\
\hline & Flood recession & 89 & 6 \\
\hline & Dry Season & 39 & 28 \\
\hline & Early rains & 11 & 33 \\
\hline \multirow[t]{5}{*}{ Otuoke } & Rainy season & 13 & 53 \\
\hline & Flood season & 9 & 56 \\
\hline & Flood recession & 75 & 3 \\
\hline & Dry Season & 63 & 13 \\
\hline & Early rains & 9 & 41 \\
\hline \multirow[t]{5}{*}{ Otakeme } & Rainy season & 6 & 81 \\
\hline & Flood season & 3 & 50 \\
\hline & Flood recession & 69 & 3 \\
\hline & Dry Season & 64 & 19 \\
\hline & Early rains & 31 & 11 \\
\hline \multirow[t]{5}{*}{ Otuogidi } & Rainy season & 13 & 63 \\
\hline & Flood season & 0 & 60 \\
\hline & Flood recession & 67 & 0 \\
\hline & Dry Season & 63 & 10 \\
\hline & Early rains & 20 & 13 \\
\hline
\end{tabular}

\begin{tabular}{|l|l|} 
Key & $0 \%$ \\
\hline None & $0>25 \%$ \\
\hline Very low to low & $25>50 \%$ \\
\hline Low to medium & $50>75 \%$ \\
\hline Medium to high & $75>100 \%$ \\
\hline High to very high &
\end{tabular}


Based on the TELK of local fishers in the sample communities, annual variations of fish production in the Kolo Creek is dependent on flood level. Increased flooding favours increased fish production. Water hyacinth, tree stumps and other tree parts in the creeks have also constrained fishing in these creeks, because tree stumps and logs from tree parts restrict access to fishing grounds. Figure 1 shows a diagrammatical summary representation of variation in fishing in the samples communities based on the TELK of Fishers. The rainy season, the flood seasons are the least viable fishing season, while flood recession season and the dry season are the most viable fishing seasons $20 \%$ of respondents have been used have the lower cut-off limits while $40 \%$ has been used as the upper cut-off limits. This implies that values less than $20 \%$ have been regarded as not significant values while values above $40 \%$ considered significant values. The lower and upper cut-off has been used, based on the premise that some of the respondents may be subjective, that some experiences may have been lost due difficulty in remembering events as it exactly occurred and that respondents may have had different experiences on fish production. Specifically, a parallel has been drawn from the study by Karr and Chu (1999), that reported that rivers with $20 \%$ or more piscivorous (carnivores) species imply minimally disturbed rivers, while rivers with $40 \%$ or more omnivore species are indication of highly degraded rivers.

\section{Figure 1 Fishing pattern in the Central Niger Delta}

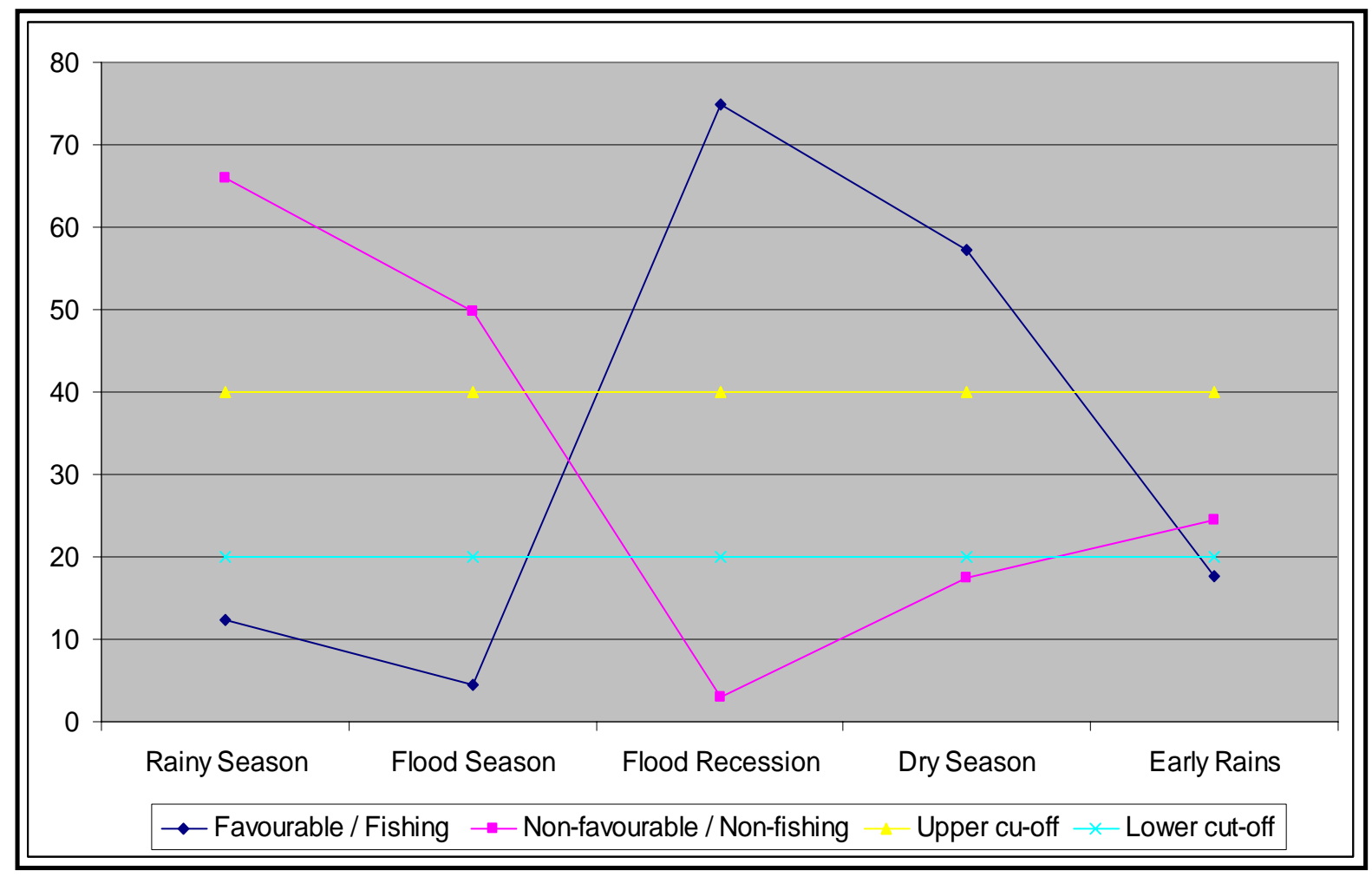


The K-S Test for normality on the data in Table 4 shows a deviation from normal distribution $(p<$ 0.05 - actual value). Kendall's tau correlation coefficient shows a significant linear relationship between the TELK of fishers in the sample communities in the Study Area. See Table 5 that contain the results of the Kendall's tau test, which implies that there is a consistent perception among fishers of the most and least viable fishing seasons in the Central Niger Delta. Using the Kruskal Wallis Test on the fishing and non-fishing seasons shows that there is no significant difference between all communities in the Study Area $(p>0.05$; fishing season $=1.00$ and nonfishing season 0.984). Generally, there is no significant difference based on the experience and knowledge of local fishers on the fishing seasons in the Study Area.

Table 5 Relationship between fishing seasons in the Central Niger Delta

\begin{tabular}{|l|l|l|l|l|}
\hline & $\begin{array}{c}\text { Fishing Season } \\
\text { (Elebele) }\end{array}$ & $\begin{array}{c}\text { Fishing Season } \\
\text { (Otuoke) }\end{array}$ & $\begin{array}{c}\text { Fishing Season } \\
\text { (Otakeme) }\end{array}$ & $\begin{array}{c}\text { Fishing Season } \\
\text { (Otuogidi) }\end{array}$ \\
\hline Fishing Season (Elebele) & 1.00 & & & \\
\hline Fishing Season (Otuoke) & $0.860^{\star \star}$ & 1.00 & 1.00 & \\
\hline Fishing Season (Otakeme) & $0.759^{\star \star}$ & $0.644^{\star}$ & $0.837^{\star \star}$ & 1.00 \\
\hline Fishing Season (Otuogidi) & $0.777^{\star \star}$ & $0.753^{\star \star}$ & & \\
\hline
\end{tabular}

**Significant at 0.01 level (2-tailed) / *Significant 0.05 level (2-tailed)

\subsection{Conclusion and recommendations}

The localised significance of inland surface water in the Central Niger Delta has been explored using the TK, TEK and TELK of inhabitants of rural communities of four rural communities in the Study Area. The information from the study has been used to represent the river use profile of rural communities of the Central Niger Delta. The use of the surface water varies across seasons and is dependent on: the quality or characteristics of the water; hydrological characteristics; biological properties and accessibility of the surface water. The surface water has a variety of use, such as for livelihood sustenance fishing, sand mining, palm processing; irrigation and lumbering; drinking and domestic purposes; for transportation and commerce purpose; sociocultural purpose such as fishing festival and recreational purpose; and for disposal of sewage and general waste. These uses imply that the inland surface water in the Central Niger Delta is of very high significance to residents of rural communities of this area of Nigeria.

Therefore, any engineering development project that significantly affects the integrity of surface water in such areas as the Central Delta could have adverse localised consequences, such as loss of livelihood sources (sand miner and fishers) and on drinking water supply. For example, until the early 1970s, the Swampy Cree community of Southern Indian depended on commercial 
fishery. In 1970, the outflow of the lake was dammed; raising the water level by several metres and the original location of the community is now submerged. Commercial fishery was adversely affected and there has been low fish catches, and poor fish quality. The community was relocated to a place with modern houses and a recreational complex. However, the recreational facilities do not seem to have replaced fishing, trapping, and hunting as a centrepiece for these people's lives. Poverty, depression, and alcohol abuse have resulted (Rosenberg, et al. 1995). Due to the failure of such top-down management strategies, there has been active interest in promoting community-based management of common pool resources (Muller and Vickers, 1996) and water resources (ARD-RAISE Consortium, 2001).

This study shows that the seasonal variation of fish production in the Central Niger Delta implies that any significant alteration of the hydrological cycle and the flow pattern of the surface water could have livelihood and nutritional consequences on resident of the rural communities in the Central Niger Delta. Generally TK, TEK and TELK have been demonstrated in this study as reliable in providing information relevant in planning for the sustainable management of natural resources that are of localised importance. Such as an approach could bring about real participation of local people in planning projects and programmes that may affect them and their livelihoods, particularly in rural communities of the developing world. 


\section{Reference}

Abam, T. K. S. (2001). "Regional hydrological research perspectives in the Niger Delta." Hydrological Sciences 46(1): 13-25.

Abam, T. K. S. and Okagbue, C. O. (1986). "Construction and performance of river bank protection structure in the Niger Delta." Bulletin of the International Association of Engineering Geology 23(4): 499-506.

Adolph, B., Butterworth, J., Conroy, C., and Morris, M. (2001). Common Pool Resources in Semi-arid India Problems and Potentials. Natural Resources Institute (NRI), Chatham, UK. Synthesis Report CRIDA / CWS / AKRSP (I) WRM Ltd. / MSU / NRI Common Pool Resources Research Project Report No. 4 (NRI Report No. 2650).

Akinluyi, T. O., and Odeyemi, O. (1984). "Human waste disposal and the faecal pollution of the River Niger Delta waters." Water International 9: 37-41.

Alagoa, E. J. (1999). The Land and People of Bayelsa Sate: Central Niger Delta. Onyoma Research Publications, Choba, Port Harcourt, Nigeria.

ARD-RAISE Consortium. (2001). Community-Based Natural Resource Management (CBNRM) in Africa - A Review. Rural and Agricultural Income with a Sustainable Environment (RAISE), Arlington, VA 22209, USA. IQC No. PCE-1-00-99-00001-00 Task 002. 66.

Beck, T., and Ghosh, M.G. (2000). Common property resource and the poor: Findings from West Bengal. Economic and Political Weekly. 35(35) 147-153.

Berkes, F. (1999). Sacred Ecology: Traditional ecological knowledge and resource management. Taylor and Francis, Philadelphia.

Berkes, F., and Colding, J., and Folke, C. (2000). "Rediscovery of traditional ecological knowledge as adaptive management." Ecological Applications 10(5): 1251-1262.

Biswas, A. K. (1997). Water Resources: Environmental Planning, Management and Development. McGraw Hill, New York.

Bolund, P., and Hunhammar, S., (1999). "Ecosystem services in urban areas." Ecological Economics 29: 293-301.

Budds, J. (1999). The role of environmental education in addressing environmental problems in Squatter settlements: Case study of Igarape do Quarenta Manaus, Brazil. Institute of Latin America Studies, University of London, London. MSc. Thesis.

Coates, D., Bovin, T., Darwall, W.R.T., Friend, R., Hirsch, P., Poulsen, A.F., Quirós, R., Visser, T.A.M., and Wallace, M. (2003). Review information, knowledge and policy. Proceedings of the Second International Symposium on the Management of Large Rivers for Fisheries, Phnom Penh, Kingdom of Cambodia, Food and Agriculture Organisation of the United Nations and the Mekong River Commission. 
Daily, G. C., Söderqvist, T., Aniyar, S., Arrow, K., Dasgupta, P., Ehrlich, P.R., Folke, C., Jansson, A., Jansson, P., Kautsky, N., Levin, S., Lubchenco, J., Mäler, K., Simpson, D., Starrett, D., Tilman, D., and Walker, B., (2000). "The value of nature and the nature of value." Science 289: 395-396.

De Groot, R., Wilson, M., and Boumans, R. (2002). "A typology for the description, classification and valuation of Ecosystem functions, Goods and Services." Ecological Economics 41(3): 367-567.

Egborge, C. E. (1980). Environmental pollution problems of small communities in the Niger Delta. Water and Waste Engineering in Africa, Kaduna, Nigeria, Proceedings of the 6th, Conference of the Water, Engineering and development Centre (WEDC), Loughborough University of Technology UK, 24 - 28 March.

Ellen, R., and Harris, H. (1996). Concepts of Indigenous environmental knowledge in scientific and developmental studies literature: A critical assessment. East-West Environmental Linkages Network Workshop 3, Canterbury 8-10 May 1996.

Fernadez-Gimenez, M. E. (2000). "The role of Mongolian Nomadic Pastoralists' ecological Knowledge in rangeland management." Ecological Applications 10(5): 1318-1326.

Field, A. (2005). Discovering statistics using SPSS. SAGE Publications Ltd., London, UK. 779.

Gadgil, M., and Berkes, F. (1991). "Traditional resources management systems." Resource Management and Optimization 8(3-4): 127-141.

Gadgil, M., Berkes, F., and Folke, C. (1993). "Indigenous knowledge for biodiversity conservation." Ambio 22(2-3): 151-156.

Ghimire, S., McKey, D., and Aumeeruddy-Thomas, Y. (2004). "Heterogeneity in ethnoecological knowledge and management of medicinal plants in the Himalayas of Nepal: implications for conservation." Ecology and Society 9(3): 6. [online] URL: http://www.ecologyandsociety.org/vol9/iss3/art6/.

Gilchrist, G., Mallory, M., and Merkel, F. (2005). "Can local ecological knowledge contribute to wildlife management? Case studies of migratory birds." Ecology and Society 10(1): 20. [online] URL: http://www.ecologyandsociety.org/vol10/iss1/art20/.

Gobo, A. E., and Abam, T.K.S. (1991). "The floods In the Niger Delta: The case of Ndoni." The Journal of Meteorology 16(163): 293-299.

Gupta, A. K., Oza, A., Pastakia, A., Saxena, R., Desai, U., and Underwood, B. (2001). Common Pool Resources in Semi-arid India: Gujarat Regional Report. Natural Resources Institute (NRI Report No. 2649). 96.

Hartmann, W., Dugan, P., Funge-Smith, S., Hortle, K.G., Kuemlangan, B., Lorenzen, K., Marmulla, G., Mattson, N., and Welcomme, R. (2003). People and fisheries management. Proceedings of the Second International Symposium on the Management of Large Rivers for 
Fisheries (Sustaining Livelihoods and Biodiversity in the New Millennium), Phnom Penh, Kingdom of Cambodia, Food and Agriculture Organisation of the United Nations and Mekong River Commission.

HRW. (1999). The Price of Oil: Corporate responsibilities and Human Rights Violations in Nigeria's Oil Producing Communities. Human Right Watch (HRW), New York, USA. http://www.hrw.org/reports/1999/nigeria/

Huitric, M. (2005). "Lobster and conch fisheries of Belize: a history of sequential exploitation." Ecology and Society 10(1): 21 [online] URL: http://www.ecologyandsociety.org/vol10/iss1/art21/. Huntington, H. P. (2000). "Using traditional ecological knowledge in science: methods and applications." Ecological Applications 10(5): 1270-1274.

Ibarra, A. A., Reid, C., and Thorpe, A. (2000). "The political economy of marine fisheries development in Peru, Chile and Mexico." Journal of Latin American Studies 32: 503-527.

Johnson, M. (2003). Research on Traditional Environmental Knowledge: Its Development and Its Role. The International Development Research Centre, Canada. http://web.idrc.ca/en/ev43097-201-1-DO TOPIC.html. 22nd April 2005.

Karr, J. R., and Chu, E.W. (1999). Restoring life in running waters: Better biological monitoring. Island Press, Washington DC.

Kgathi, D. L., Kniveton, D., Ringrose, S., Turton, A. R., Vanderpost, C. H. M., Lundqvist, J. and Seely, M. (2006). "The Okavango; a river supporting its people, environment and economic development." Journal of Hydrology 331: 3-17.

Klubnikin, K. A., C., Cherkasova, M., Shishin, M., and Fotieva, I. (2000). "The sacred and the scientific: traditional ecological knowledge in Siberian River conservation." Ecological Applications 10(5): 1296-1306.

Koranteng, K. A., Ofori-Dason, P.K. and Entsua-Mensah, M. (2000). "Fish and fisheries of the Muni lagoon in Ghana, West Africa." Biodiversity and Conservation 9: 487-499.

Laë, R., Williams, S., Malam Massou, A., Morand, P., and Mikolasek, O. (2003). Review of the present state of the environment, fish stocks and fisheries of the river Niger (West Africa). Proceedings of the Second International Symposium on the Management of Large Rivers for Fisheries (Sustaining Livelihoods and Biodiversity in the New Millennium), Phnom Penh, Kingdom of Cambodia, Food and Agriculture organisation of the United Nations and the Mekong River Commission.

Maass, J., Balvanera, P., Castillo, A., Daily, G. C., Mooney, H.A., Ehrlich, P., Quesada, M., Miranda, A., Jaramillo, J.V., García-Oliva, F., Martínez-Yrizar, A., Cotler, H., López-Blanco, J., Pérez-Jiménez, A., Búrquez, A., Tinoco, C., Ceballos, G., Barraza, L., Ayala, R., and Sarukhán, J (2005). "Ecosystem services of tropical dry forests: insights from long-term ecological and social research on the Pacific Coast of Mexico." Ecology and Society 10(1): 17. [online] URL: http://www.ecologyandsociety.org/vol10/iss1/art17l. 
Miller, G. T., Jr. (2002). Living in the Environment: principles, connections, and solutions. Brooks/Cole Thomas Learning, Stamford, USA.

Muller, A., and Vickers, M. (1996). Communication in a Common Pool Resource Environment with Probabilistic Destruction. Department of Economics, McMaster University, Working Paper, 96-106.

Nabhan, G. P. (1997). Cultures of habitat: on nature, culture, and story. Counterpoint, Washington D.C., USA.

Nepal, S. K. (2002). "Involving indigenous peoples in protected area management: comparative perspectives from Nepal, Thailand, and China." Environmental Management 30(6): 748-763.

Okagbue, C. O. (1989). "Geotechnical and environmental problems of the Niger Delta." Bulletin of the International Association of Engineering Geology.

Olsson, P., and Folke, C. (2001). "Local ecological knowledge and institutional dynamics for ecosystem management: a study of Lake Racken watershed, Sweden." Ecosystems 4: 85-104.

Osman, M., Mishra, P. K., Mishra, A. K., Dixit, S., Ramachandran, K., Singh, H. P., Rama Rao, C. A., and Korwar, G. R. (2001). Common Pool Resources in Semi-arid India: a review of dynamics, management and livelihood contributions. Natural Resources Institute (NRI), Kent, United Kingdom.

Paci, C., Tobin, A., and Robb, P. (2002). "Reconsidering the Canadian Environmental Impact Assessment Act a place for traditional environmental knowledge." Environmental Impact Assessment Review 22: 111-127.

Rosenberg, D. M., Bodaly, R.A., and Usher, P.J. (1995). "Environmental and social impacts of large-scale hydro-electric development: who is listening?" Global Environmental Change $\mathbf{5}$ : 127-148.

Sallenave, J. (1994). "Giving traditional ecological knowledge its rightful place in environmental impact assessment." Northern Perspectives 22(1): 8. http://www.carc.org/pubs/v22no1/know.htm 06/11/2002.

Sarch, M. T. (2001). "Fishing and farming at Lake Chad: Institutions for access to natural resources." Journal of Environmental Management 62: 185-199.

Sikoki, F. D., and Otobotekere, A.J.T. (1999). Chapter 24: Fisheries. In The Land and People of Bayelsa State: Central Niger Delta. Alagoa, E. J. Onyoma Research Publications, Port Harcourt, Nigeria: 411.

Sillitoe, P., Dixon, P., and Barr, J. (2002). Indigenous Knowledge Methodology. (Anthropology Department, University of Durham and Centre for Land Use and Water Resources Research University of Newcastle) for Department for International Development (DFID), London. 
Tamuno, P. B. L. (2001). Flood mitigation: a case study from Bayelsa State, Nigeria. Water, Engineering and Development Centre (WEDC), Loughborough University, Loughborough, UK. 161. MSc Thesis.

Tamuno, P. B. L., Ince, M.E., and Howard, G. (2003b). Understanding vulnerability in the Niger floodplain. Towards the Millennium Development Goals Actions for Water and Environmental Sanitation., Abuja, Nigeria, Proceedings of the 29th Water, Engineering and Development Centre (WEDC), Loughborough University, UK.

Tamuno, P. B. L., Smith, M. D., Howard, G., Adesope, M. O. and Bawo, D. D. S. (2007). "Analysis of livelihood characteristics of selected fishing communities in the Central Niger Delta, Nigeria." Journal of Agriculture and Social Research (JASR) 7(1): 34-42.

Trebaol, L. (2003). "EIA of the Adjarala hydroelecteric project (Togo-Benin): the aquatic environment component." AJEAM-RAGEE 5: 55-65.

Turner, N. J., Ignace, M.B., and Ignace, R. (2000). "Traditional ecological knowledge and wisdom of Aboriginal peoples in British Columbia." Ecological Applications 10(5): 127-1287.

UNEP. (1998). Report of the fourth meeting of the conference of the parties to the convention on biological diversity. United Nations Environmental Programme (UNEP), Nairobi, Kenya.

Warren, D. M., and Rajasekaran, B. (1993). "Putting local knowledge to good use." International Agricultural Development 13(4): 8-10.

Wolfe, J., Bechard, C., Cizek, P., and Cole, D. (1992). "Indigenous and Western knowledge and resource management systems." Rural Reporting Native Canadian Issues, Series, 1. 